\title{
A PEDOMETER-BASED WALKING PROGRAM IN AN ASSISTED-LIVING SETTING: A PILOT STUDY
}


Tampereen yliopisto

Lääketieteen yksikkö

Geriatrian tutkimusryhmä

\section{KIRVESMÄKI VIIVI : A PEDOMETER-BASED WALKING PROGRAM IN AN ASSISTED-LIVING SETTING: A PILOT STUDY}

Syventävien opintojen kirjallinen työ, $9 \mathrm{~s}$.

Ohjaaja: professori Jaakko Valvanne

Julkaistu Gerontechnology-lehdessä 2015;13(3):368-376

doi: 10.4017/gt.2015.13.3.009.00

Lokakuu 2015

Avainsanat: iäkkäät, askelmittari, päivittäiset askeleet, teknologian käytettävyys

Liikunta on iäkkäille elintärkeää fyysisen toimintakyvyn säilyttämiseksi. Liikunnan lisäämiskeinoja on tutkittu paljon, mutta tutkimus on keskittynyt paljolti kotona asuviin. Tässä pilottitutkimuksessa selvitettiin, miten aikaisemmissa tutkimuksissa "tarpeeksi hyväksi" todettu askelmittari soveltuu liikunnan lisäämiseen palvelutalossa asuvilla.

Pilotti koostui seitsemän viikon kävelyohjelmasta, jossa tarkoituksena oli asteittain lisätä askelmääriä henkilökohtaisesta perustasosta. Tutkimukseen osallistui kahdeksan keski-iältään 81-vuotiasta palvelutalon asukasta. Huomiota kiinnitettiin erityisesti tutkittavien ja hoitajien kokemuksiin mittarin käytöstä, motivoinnin keinoihin sekä askelmäärien seurantaan.

Alussa tutkittavien askeleiden perustasojen mediaani oli 800 askelta (päivittäinen keskiarvo 1369). Kävelyohjelman lopussa mitattuna tutkittavien askeleet eivät olleet tilastollisesti merkitsevällä tavalla lisääntyneet. Sekä tutkittavat että hoitajat raportoivat että osa iäkkäistä lisäsi liikunnallista aktiivisuuttaan askelmittarin käytön myötä. Samalla kuitenkin raportoitiin mittarin tarkkuuteen, kiinnitykseen sekä käyttöön liittyneistä ongelmista.

Askelmittariin perustuvan kävelyohjelman toteuttaminen palveluasumisyksikössä todettiin mahdolliseksi, joskin haastavaksi. Tulevaisuuden interventioissa tulee kiinnittää huomiota avoimeen kommunikaatioon hoitohenkilökunnan ja tutkijaryhmän välillä. Askelmittarien tarkkuus ei vielä näytä riittävältä toimintarajoitteisten ikäihmisten liikkumisaktiviteetin seuraamiseen. Tarve erityisesti iäkkäille suunnitelluille askelmittareille on ilmeinen. 


\section{SISÄLLYSLUETTELO}

ABSTRAKTI IOHA




\title{
Original
}

\section{A pedometer-based walking program in an assisted-living setting: A pilot study}

\author{
Viivi Kirvesmäki MS \\ Clas-Håkan Nygård $\mathrm{PhD}^{\mathrm{b}, \mathrm{c}}$ \\ Reetta Rutanen $\mathrm{MSc}^{\mathrm{b}, \mathrm{c}}$ \\ Tarja Heinonen MSc ${ }^{\text {b,d }}$ \\ Pirjo Lindfors $\mathrm{PhD}^{\mathrm{b}}$ \\ Jaakko Valvanne MD PhD ${ }^{\text {a,c,e }}$
}

\begin{abstract}
${ }^{2}$ School of Medicine, University of Tampere, Tampere, Finland, E: kirvesmaki.viivi.i@student.uta.fi; bSchool of Health Sciences, University of Tampere, Tampere, Finland; 'Gerontology Research Center, Universities of Jyväskylä and Tampere, Finland; 'Tampere University of Applied Sciences, Tampere, Finland, 'Tampere University Hospital, Tampere, Finland
\end{abstract}

V. Kirvesmäki, C-H. Nygård, R. Rutanen, T. Heinonen, P. Lindfors, I. Valvanne. A pedometer-based walking program in an assisted-living setting: A pilot study. Gerontechnology 2015;13(3):368-376; doi:10.4017/gt.2015.13.3.009.00 Purpose Physical activity is a key to independent functional ability among older adults but few interventions have been conducted in assisted-living residences. A pedometer has been stated to be 'a good-enough' measuring device for the assessment of walking activity in older populations. Research has, however, focused more on community dwelling older adults than on those residing in assisted-living facilities. The aim of this pilot study was to assess the feasibility of a pedometer based walking program in an assisted-living facility, and to explore the challenges and obstacles for the implementation of such a program. Materials and methods A pilot intervention study was done with 8 residents between 68 and 89 years of age residing in one assisted-living facility in Finland. The participants were given pedometers and were asked to walk as usual for a period of one week in order to measure the baseline number of steps. Then, personal goals were assessed based on these baseline figures. Motivational materials and meetings with the participants and attendant nurses were also provided. Participants were encouraged to increase their daily number of steps from their baseline levels by $5 \%$ weekly for a period of 6 weeks. Post intervention, seven of the participants and their nurses $(n=13)$ filled in questionnaires concerning the use and usability of the pedometer. Results At baseline, the median number of steps taken by the participants was 800 per day, the daily average being 1369 . Post intervention the median was 884 and daily average 1458 steps, demonstrating an increase but no statistically significant changes in the number of steps. Most of the nurses $(9 / 13)$ believed the pedometer actually encouraged the residents to walk more, but because of technical difficulties, fewer nurses $(5 / 13)$ found the pedometer to be useful in practice in terms of encouragement for more activity. The participants and nurses found the pedometer easy to use but reported problems with it falling off, underestimating step counts, and inaccuracy. Conclusion Motivating sedentary older adults living in an assisted-living facility to walk more by employing a pedometer-based walking program is possible but challenging. Integrating the program into daily routines and systematic communication between the research team and the staff of the participating site are needed in order to support the adoption and sustained usage of the new technology. The accuracy and reliability of the pedometer need improvement in terms of use by people with shuffling and low-impact gaits. Better clips to prevent dislodging as well as easier to read numbers are also recommended. Overall, the findings from this study suggest that there is a need for improved pedometer technology to be used with older adults residing in assisted-living residences.

Keywords: older adult, daily steps, motivation, human factors, adoption of technology

'The Physical Activity Guidelines for Americans', published by the United States Government, reports that adults aged 65 years and older are the least physically active of all age groups'. Older adults gain substantial health benefits from regular physical activity, and these benefits persist 2015 throughout their lifetime. In addition, the report notes that 'strong evidence indicates that being physically active is associated with higher levels of functional health, a lower risk of falling, and better cognitive functioning'. The very oldest also represent a group that extensively requires 


\section{Ped ometer-based walking}

long-term care and services from nursing homes, sheltered housing, or assisted-living facilities' ${ }^{1}$.

Assisted-living facilities provide medical and nursing care to people who are unable to live independently in the community ${ }^{2}$. The level of care is similar to that provided in traditional nursing homes or long-term hospital wards, but the environment is designed to be more homelike ${ }^{2}$. Approximately $70 \%$ of residents in assisted-living facilities and nursing homes in Finland have at least moderate cognitive impairment and/or a moderate or severe dependency for assistance due to limitations in their daily functional abilities $^{3}$. The amount of exercise by these people is generally considered to be on a below normal level. However, the beneficial health effects of physical activity in all ages are well documented, and exercise is also beneficial for frail older adults ${ }^{4}$. According to a meta-analysis, exercise resulted in improvements in health-related physical fitness and cognitive functions among the older adults with cognitive impairment and dementia ${ }^{5}$. On the other hand, various difficulties can arise while conducting interventions with older adults living in longterm care; examples of such difficulties include, among others, factors related to long-term care facilities, the nursing staff, the research team, and the institutionalized older adults themselves ${ }^{6}$.

Walking is a feasible, safe and easy way of exercising in long-term care settings. Older adults' ambulatory activity has been monitored by nursing reports and self-reporting, but such reports are subject to bias and may under- or overestimate an individual's true ambulatory activity 7,8 . Motion sensors, for example pedometers, are more appropriate for the quantification of physical activity behaviors in typically sedentary population $s^{8}$. Pedometers are affordable and a "good enough" measure of physical activity, specifically ambulatory activity ${ }^{8}$. Pedometers have been shown to efficiently increase the daily ambulatory activity and health of communitydwelling older adults ${ }^{9 \cdot 11}$. However, a pedometer alone does not provide sufficient motivation for substantially increasing the ambulatory activity. According to a systematic review, setting a personalized step goal and the use of a step diary may be additional key motivational factors for increasing physical activity ${ }^{9}$. In younger age groups, the recommended number of steps per day is 10,000 . In a review, Tudor-Locke estimated that a range between 2,000 and 9,000 steps per day is likely to reflect the true variability of physical activity behaviors in older populations ${ }^{12}$. The amount of ambulatory activity in assistedliving facilities or in a nursing home setting remains unknown, so interventions carried out in long-term care should utilize an individualized goal-setting rather than to set the same goals for all participants".

When interventions are carried out in long-term care settings, it falls on both the nursing staff and the patient him/herself to support the commitment to the goal ${ }^{13}$. In order to provide continuity for the rehabilitation process, the commitment of the whole nursing staff is crucial ${ }^{14}$. Nursing that promotes rehabilitation maintains or restores functional ability and increases life satisfaction and physical and social well-being ${ }^{15}$. According to Routasalo et al., nursing staff are aware of the importance of motivation in rehabilitation, and they understand that older adults gain more benefit from motivation than from physical help ${ }^{15}$. Hsu and Chen pointed out that creating and maintaining an ongoing communication with the nursing staff are important facilitators of a successful intervention study ${ }^{6}$. The study is more likely to succeed if the research team adjusts to the participating sites' daily timetables and shows that it appreciates the nursing staffs involvement in the study process ${ }^{6}$.

Research evaluating the efficacy of exercise among older adults, ${ }^{9,16}$ and also studies with pedometer-based programs ${ }^{10,17}$ have primarily been conducted with relatively healthy community-dwelling individuals as participants; it may therefore not be possible to generalize the result to apply to older adults living in assistedliving settings. There is a major difference in functional ability between the general population of older adults and those who participate in intervention studies, so intervention studies among older adults living in long-term care are urgently needed ${ }^{18}$. Indeed, only a few studies to date have examined the use of pedometers in a nursing-home setting ${ }^{19,20}$. Cohen-Mansfield et al. reported that the devices were easy to use and well-tolerated $^{19}$. However, Cyarto et al. noted that pedometers underestimate the steps taken by the elderly at lower walking speeds, and that more accurate options for quantifying physical activity are needed among mobility-impaired populations, such as nursing-home residents ${ }^{20}$.

It therefore remains unclear whether a pedometer-based walking program would be feasible and effective among older adults living in an assistedliving setting. The goal of the present sevenweek study was to evaluate whether a pedometer-based walking program has the potential to increase the amount of daily steps taken by older adults in this clinically relevant group. The present trial is a pilot study that primarily assessed the feasibility of a pedometer-based walking program and sought to discover the challenges and obstacles in im- 


\section{Pedometer-based walking}

plementing such a program among frail residents living in an assisted-living setting.

\section{Metrods \\ Participants}

The research design was a pilot intervention study conducted at a private assisted-living facility in Finland during the summer of 2013. The participating site was chosen because of access through employment of one of the researchers (VK) as a summer nurse in the facility. The participating site was a combination of an assistedliving residence and a nursing home but the intervention was only conducted in the assistedliving residence.

Recruitment was twofold. First a senior researcher (JV) had a two-hour visit at the residence to increase the administration, staff's and residents' understanding of the project and commitment to the research process. Residents were screened by VK to assess their eligibility to participate. Older adults unable to walk with or without a walking aid were excluded. Next, all the residents were screened for cognitive impairment using the 30-point Mini-Mental State Examination ${ }^{21}$. Those who scored under 18 points (moderate or severe dementia) were excluded. The inclusion criteria were a willingness to participate, the ability to walk with or without a walking aid, and sufficient cognition to understand the purpose of the study. All 24 residents of the site's assisted-living residence were asked to participate in the study, 11 agreed to start the intervention with 7 completing it. There were 25 nurses working at the residence at the time of the study, and all of them participated in the implementation of the study. A written informed consent was obtained from all participants, and the study was approved by the Regional Ethics Committee of Tampere University Hospital and the participating site.

\section{Study design and procedures}

The study procedures (Table 1), the collection of data and counseling of participants were conducted by VK. During the first week, the participants were asked to wear the pedometer (Omron Walking style PRO, model HJ-702IT-E2, Finland) and to proceed at their usual level of activity. They were advised to attach the pedometer to their clothing near the hip to minimize the measuring error ${ }^{20}$ and to wear it during all waking hours. The nursing staff was asked to assist the participants record the number of steps taken every evening.

The data from the first week of walking was transferred from the pedometers to a computer and analyzed with a commercial program (the Om- ron Health Management program). This weekly average number of steps defined the baseline level for each participant. The goal was to achieve a weekly increase of $5 \%$ in the number of steps.

The researcher arranged a one-hour information meeting with the nursing staff, in which evidence-based information on the effectiveness of the increase of physical activity to older adults' health, functional ability, and mental health was discussed. Practical information about the use of the pedometer was also provided, and the nurses were given an opportunity to learn how to use the pedometer for one week. The nurses were asked to ensure that the older adults actually wore the pedometer, and to encourage participants during the day to independently reach their step goals. Weekly meetings were held with the assisted-living facilities' staff as

\begin{tabular}{|c|c|}
\hline Week $\#$ & Action \\
\hline \multirow[t]{6}{*}{0} & -Memory assessment (MMSE) \\
\hline & -Vision assessment \\
\hline & -Written informed consent \\
\hline & $\begin{array}{l}\text {-Assessment of physical ability to function } \\
\text { (Barthel) }\end{array}$ \\
\hline & -Quality of life assessment (EuroHIS) \\
\hline & $\begin{array}{l}\text {-Instructions on the use of the pedometer } \\
\text {-Study information to the nursing staff }\end{array}$ \\
\hline \multirow[t]{2}{*}{1} & -The daily use of the pedometer starts \\
\hline & $\begin{array}{l}\text {-At the end of the day, the number of steps is } \\
\text { recorded in the step chart }\end{array}$ \\
\hline \multirow[t]{8}{*}{2} & -Physical exercise guidance with the UKK \\
\hline & $\begin{array}{l}\text { Institute's Physical Activity Pie, a graphic aid } \\
\text { to health-enhancing physical activity }\end{array}$ \\
\hline & -Individual goals at the beginning of the week \\
\hline & ( $5 \%$ more than the baseline number of steps) \\
\hline & -Weekly goals are recorded in the step chart \\
\hline & $\begin{array}{l}\text {-The staff encourages the participant to } \\
\text { reach each week's goal }\end{array}$ \\
\hline & $\begin{array}{l}\text {-At the end of the day, the number of steps is } \\
\text { recorded in the step chart }\end{array}$ \\
\hline & $\begin{array}{l}\text {-Incidents that might affect the number of } \\
\text { steps are recorded in the step chart }\end{array}$ \\
\hline \multirow[t]{6}{*}{$3-7$} & -Individual goals are assessed each week (a \\
\hline & $5 \%$ increase in steps each week) \\
\hline & -Weekly goals are marked in the step chart \\
\hline & $\begin{array}{l}\text {-The staff encourages the participant to } \\
\text { reach each week's goal }\end{array}$ \\
\hline & $\begin{array}{l}\text {-At the end of the day, the number of steps is } \\
\text { recorded in the step chart }\end{array}$ \\
\hline & $\begin{array}{l}\text {-Incidents that might affect the number of } \\
\text { steps are recorded in the step chart }\end{array}$ \\
\hline \multirow[t]{6}{*}{8} & -Intervention ends \\
\hline & $\begin{array}{l}\text {-Pedometers are collected from the } \\
\text { participants }\end{array}$ \\
\hline & -Assessment of physical ability to function \\
\hline & (Barthel) \\
\hline & -Quality of life assessment (EuroHIS) \\
\hline & -Usability questionnaire (SUS) to participants \\
\hline
\end{tabular}




\section{Pedometer-based walking}

usual, also providing the researcher the opportunity to hear the nurses' views on the progress of the walking program, and to get an update of news from the intervention. The changing weekly goals were marked on the step chart on a visible place on the wall of each participant's room. The participants marked their daily steps on the chart, making it easy for the participant and also for the nursing staff to follow the step counts, and to keep motivating the participant to reach their goals.

No changes were made in the assisted-living facilities' normal activity schedule. The usual weekly physical exercise hour was held as before, and the study participants could participate along with the other residents. U.S. Government-published ${ }^{1,22}$ motivational visual material about the health benefits of physical exercise for older adults were individually given to all participants at the beginning of week 2 . The researcher explained how even a small increase in the amount of walking could have a significant effect on functional ability, mood and sleep. Participants received weekly individual 15 -minute meetings with the researcher in study weeks 2 to 6. The data from the pedometer was transferred to computer and the new goals were assessed. The purpose of the weekly meetings was to give feedback on the previous week's outcomes and to clarify the next week's step goals to the participants. Concrete examples on how to reach the step goal, such as "walk the length of the corridor twice before coming to lunch" were given.

\section{Outcome measurements}

The primary outcome measure was the average number of steps counted daily by the pedometer. The pedometer has been previously tested in clinical settings, and its reliability has been demonstrated ${ }^{23}$. Secondary outcomes included functional ability and quality of life-measures. Functional ability was measured with the Barthel inde ${ }^{24}$. The scale ranges from zero to 100 , and the scores are interpreted as: $0-20$ total dependency, 21-60 severe dependency, 61-90 moderate dependency and 91-100 independent of assistance from others.

Quality of life was measured with the EUROHIS-Qol 8-item index ${ }^{25}$, which is a truncated version of the WHOQOL-BREF-scale. The eight questions concern quality of life, health, vitality, self-esteem and financial issues. The respondent chooses the most suitable answer on a Likert scale (range 1-5), and the average numbers of points are calculated. The maximum score per question is 5 points, showing good quality of life. This index has previously been used in population-based research concerning patients with dementia ${ }^{26}$. All the outcome measures were administered at the beginning of the study and repeated after the intervention.

In addition, after the intervention, the feasibility of use of the pedometer was assessed from the participants' point of view using the System Usability Scale (SUS)-questionnaire, which can be used to assess the usability of various products or services ${ }^{27}$. There are 10 statements in the SUS questionnaire. The questions cover aspects concerning effectiveness, efficiency and user satisfaction ${ }^{27}$. The responses are given on a scale from 1 (totally disagree) to 5 (totally agree). The total score in the questionnaire varies between 0 and 100 . According to a seven-step adjectiveanchored Likert scale described by Bangor ${ }^{28}$ a median of 91 points=best imaginable, $86=$ excellent, 71=good, 51=OK, 36=poor, $20=$ awful and $13=$ worst imaginable. In this study, questions 5 ("Various functions of the pedometer were wellintegrated") and 6 ("There was too much inconsistency in this product") were excluded because the participants only used one function of the pedometer (daily step counts). The use of other functions such as calculating anaerobic step counts or walking distance measurements were not available to our participants, and therefore those two questions were excluded. The two excluded questions were calculated in the final SUS scores as center point of the scale (3) as recommended by Brooke ${ }^{27}$. The questionnaire had six additional open-ended questions concerning the positive and negative aspects of the pedometer, its usability and impact on health, if any. Furthermore, the nurses' viewpoints on the use of the pedometer were evaluated post-intervention using a questionnaire with four open-ended questions. All the answers to the open-ended questions were analyzed by one of the researchers (PL) using content analysis.

\section{Results}

\section{Study flow and outcome}

Baseline characteristics are shown in Table 2. In the screening phase, 4 participants were excluded because of their inability to walk independently, 5 due to poor performance in the MMSE-test, and 5 refused to participate. Eleven of the 24 residents were eligible and agreed to participate in the pilot study. Of these, 3 participants dropped out during the first week of the intervention: one considered the pedometer to cause too much stress, one dropped out due to cognitive challenges with the pedometer, and one dropped out due to frustration caused by pedometer inaccuracy. Cognitive skills, functional ability, and quality of life ratings of these three participants were not significantly different from the study group. The final study group com- 


\section{Ped ometer-based walking}

Table 2. Baseline characteristics of the participants; *=questions with drawing assignments were ruled out due to vision impairments; **=range: $68-89 \mathrm{yrs}$

\begin{tabular}{c|ccc}
\hline Participant \# & Age, yrs & Gender & MMSE score \\
\hline 1 & 89 & male & $28 / 30$ \\
2 & 80 & male & $21 / 30$ \\
3 & 88 & female & $27 / 30$ \\
4 & 88 & female & $21 / 27^{*}$ \\
5 & 76 & female & $20 / 30$ \\
6 & 69 & male & $23 / 26^{*}$ \\
7 & 68 & female & $18 / 30$ \\
8 & 86 & male & $20 / 30$ \\
Average & $80.5^{* *}$ & & \\
\hline
\end{tabular}

prised of four women and four men, a total of 8 participants with mean age of 80.5 (range 68$89)$ years. Their MMSE-scores ranged from 18 to 28 , corresponding to mild dementia or normal cognition (Table 2). One participant dropped out of the study on week six due to a hospitalization not related to the study intervention. This participant's step counts were included in the analysis.

The Barthel index showed that the study group's ability to function varied between moderate assistance dependency to being independent ( $\mathrm{Ta}$ ble 2). In the comparison of values before and after the intervention, no improvements were observed in the quality of life measured by the EuroHIS-questionnaire $(p=0.888)$ or the functional ability measured by the Barthel index $(p=0.317)$. During the intervention, the nurses and the researcher followed the participants' use of the pedometer and reminded them to collect and clip it on again if they noticed that the pedometer was missing. No adverse events related to the intervention were reported.

\section{Walking program}

The aim of the pedometer-based walking program was to increase the participants' daily steps from the base level by an average of $5 \%$ or more weekly. The baseline median of daily steps (the average of the first week) was 800 , and most of the participants' daily step counts were lower than 1500 steps. The average step count in the baseline week was 1369, and during the last week of the intervention, the count was 1458, the median being 884 steps (Table 3). Although the number of steps increased, the difference was not statistically significant, and the target increase of $30 \%$ was not accomplished. On the other hand, there were five study weeks with progressive step goals for each participant, and when the numbers of weeks in which the original goals of each participant were achieved were added together, the results indicated that the participants reached their individual target step values in 20 weeks out of 40 . One of the participants (number 2) dropped out of the intervention due to hospitalization and the decrease of steps before the illness was evident in the data analysis.

\section{Older adult's experience}

Participants gained an average of 64 points out of 100 in the SUS questionnaire, representing midrange usability value 'OK' ${ }^{28}$. In the questionnaire (Table 4), five of the seven respondents answered that they would not need technical support to be able to use the pedometer. As a matter of fact, participants (6 responses) believed that most people could learn how to use the pedometer quickly. On the other hand, five of the participants would not like to use the

Table 3. Pre and post outcome $(n=8)$ as tested with Wilcoxon Signed-Rank Test; * =weekly average of daily steps; $x=$ missing value

\begin{tabular}{|c|c|c|c|c|c|c|c|c|c|c|c|}
\hline \multirow{2}{*}{ Parameter } & & \multicolumn{8}{|c|}{ Participant } & \multicolumn{2}{|c|}{ Outcome } \\
\hline & & 1 & 2 & 3 & 4 & 5 & 6 & 7 & 8 & Average & $p$ \\
\hline \multirow[t]{2}{*}{ Steps* } & Before & 2207 & 1872 & 131 & 845 & 4393 & 755 & 593 & 155 & 1369 & \\
\hline & After & 2633 & $\mathrm{x}$ & 92 & 884 & 4763 & 451 & 1074 & 311 & 1458 & 0.15 \\
\hline \multirow[t]{3}{*}{ EuroHIS } & Before & 4.1 & 2.6 & 4.1 & 3.1 & 4 & 2.8 & 3.3 & 3.4 & 3.4 & \\
\hline & After & 3.9 & $\mathbf{x}$ & 3.9 & 4 & 3.9 & 3 & 3.8 & 3.3 & 3.7 & 0.888 \\
\hline & Before & 100 & 70 & 85 & 100 & 100 & 95 & 70 & 100 & 90 & \\
\hline Barthel index & After & 100 & 70 & 85 & 100 & 100 & 95 & 70 & 100 & 90 & 0.317 \\
\hline
\end{tabular}

Table 4. Elements of SUS (System Usability Score); Likert scale: 1=strongly disagree, 5=strongly agree

\begin{tabular}{l|c|c|c|c|c}
\hline \multirow{2}{*}{ Item } & \multicolumn{4}{|c}{ Likert scale frequency (n=7) } \\
\cline { 2 - 5 } & $\mathbf{1}$ & $\mathbf{2}$ & $\mathbf{3}$ & $\mathbf{4}$ & $\mathbf{5}$ \\
\hline I would like to use the pedometer frequently & 4 & 1 & 0 & 1 & 1 \\
The pedometer was unnecessarily complex & 2 & 3 & 1 & 0 & 1 \\
The pedometer was easy to use & 1 & 0 & 1 & 2 & 3 \\
I would need technical support to be able to use the pedometer & 5 & 1 & 0 & 0 & 1 \\
Most people could learn how to use a pedometer quickly & 0 & 0 & 1 & 2 & 4 \\
The pedometer was very awkward to use & 4 & 2 & 0 & 0 & 1 \\
I felt very confident using the pedometer & 1 & 1 & 1 & 3 & 1 \\
I had to learn many things before I could start using the pedometer & 4 & 1 & 0 & 1 & 1 \\
Total votes & 21 & 9 & 4 & 9 & 13 \\
\hline
\end{tabular}




\section{Pedometer-based walking}

pedometer frequently. In the questionnaire's open-ended questions, the majority of the participants responded that the most interesting feature of wearing a pedometer was the ability to follow daily step counts (5 responses). Users commented that "it was nice to check the steps from the pedometer". When they were asked whether the pedometer and the walking program had any influence on their physical activity levels, half of the participants responded that "the pedometer really motivated me to walk more". The other half responded that "pedometer had no positive impact" or "it did not encourage me to exercise more". Three participants reported problems with pedometer attachment to waist and complained that the pedometer fell off easily when walking. Two participants also made negative comments about the pedometer's ability to count the steps accurately: "I walked a long way, and the numbers on the pedometer did not increase. It was a waste of time".

\section{Nurse opinion}

After the study, 13 out of the 25 participating nurses responded to a short questionnaire with four open-ended questions. When asked about whether the informing, the objectives and significance of the study had become clear to nursing staff in the information meetings, all of the nurses answered that the information given by the researcher was sufficient. When the nurses were asked about the most substantial benefit of the pedometer to the participants, they commented that "those who participated in the study increased their daily exercise" (9 respondents) and "some even exceeded themselves" (1 respondent). Some reported that the impact of the pedometer was only temporary, and after the intervention the amount of walking decreased ( 3 respondents). When asked: "Would a pedometer be useful to you in your work?", 5 nurses regarded the pedometer as useful in increasing the physical activity level of older adults, especially for independent walking. However, 4 of the nurses saw no benefit in using a pedometer to increase older adults' activity. They expressed negative comments, such as "pedometers created too much stress and anxiety among older adults" ( 3 respondents) and "some participants felt that they were forced to walk every day even if the weather was bad" ( 3 respondents).

\section{Discussion}

In this pilot study, the median number of older adults' daily steps was only 800 steps per day, and most of the participants walked less than 1500 steps per day. These findings suggest that the step counts among the elderly living in an assisted-living setting might be lower compared to community-dwelling older adults of the same age $^{11,12}$. The step counts in our pilot study were closer to the ambulatory activity (740 steps per day) measured in older populations hospitalized with acute medical illness ${ }^{29}$. Based on previous research, we were aware of possible limitations in the testing of the pedometer in older age groups where pedometers have not been properly tested before. Nevertheless, the inconsistency of the pedometer step counting among participants with walking aids, shuffling gait, low amplitude of the foot strike, and low walking speed surprised us. Our pilot study findings may indicate that the pedometer might not be 'a good-enough' sensitive step measuring device for older adults living in assisted-living settings, thus disagreeing with previous research ${ }^{8}$.

The pedometer's variability in accuracy noticed in the first week of the intervention may have influenced the final outcome negatively. The 3 drop-outs were caused by problems in the interaction between the device and the people who used them. Evidence shows that lack of attention to human factors and ergonomics in the design and implementation of healthcare technologies can result in poor quality of care and cause patient safety incidents ${ }^{30,31}$.

The pedometers were considered easy to use. This concurs with other studies on pedometer use in older adult populations ${ }^{11,19}$. However, the usability rating assessed by means of the SUS questionnaire was only 64 points, indicating an 'OK' usability and leaving many opportunities for improvements. Most of the participants in our pilot study found it interesting to follow the step counts during the day. One half of the group reported that the follow-up encouraged them to take more steps, and the other half answered that the pedometer had no influence on their motivation to increase their daily activity levels. This result might indicate that human factors issues, such as pedometer inaccuracy, affected the participants' motivation and lead to technology not being adopted. In line with our pilot study results, Cyarto et al. ${ }^{20}$ reported that pedometers underestimate the number of steps taken at lower walking speeds by nursing home residents compared to a community-dwelling group. They also reported that gait-impairment scores contributed to the pedometer's inability to detect steps taken, and concluded that pedometers are not acceptably accurate for quantifying physical activity in frail, institutionalized older adults.

In addition, the methods of motivating the nursing staff are crucial when trying to change the exercise culture among older adults living in nursing facilies ${ }^{13}$. Fewer than half of the nurses at the participating site considered the pedometer to be useful in motivating the elderly to walk 


\section{Pedometer-based walking}

independently. This outcome indicates that the technology used was not well-adopted. The most substantial reason behind no tech adoption might have been the inaccuracy of the pedometer. Without a reliable and accurate measuring device, no widespread tech adoption can be expected. It is understandable that the nurses do not want elders to get upset by forcing them to use impractical technology.

The dialogue between the researchers and the staff should be sincere and straightforward so that possible barriers could be noticed and diffused straight away. In this study the weekly meetings were not always held, and constructive discussion about pedometer issues did not develop. In future research, one solution could be to have the nurses participate in the data transfer process. The computer program used in this intervention (Omron Health Management Program) creates various graphs based on the numbers of daily steps, and discussing the graphs with the nurses could have led to better technology adoption. In the future, one of the possible advantages of the pedometer might be that the changes in the older adults' health could be noticed and anticipated by following the step counts by means of graphs. In this study, the phenomenon of decreasing step counts before the illness was noticed before the hospitalization of participant 2 .

Research and evidence-based nursing practices are novelties in nursing science, and nurses might be unwilling to change nursing procedures ${ }^{32}$. The key to resolving this problem would be to identify champions in the nursing staff who embrace the idea of pedometer use and foster acceptance among team mates. The study information was considered sufficient by the nurses, but only half of the nurses responded to the questionnaire after the intervention. Changes in work shifts created a challenge for the maintenance of nurse continuity for weekly study updates and resident coaching to promote walking. In future research, any mismatch between the expectations and needs of the researchers and the end users could be revealed in well-planned regular meetings with the nursing staff. Positive motivators, for example free lunch sessions could be offered to the nurses ${ }^{6}$.

Enrolling older adults to participate in this study was more challenging than we expected. Johnson and colleagues ${ }^{33}$ also discovered that when enrolling participants in assisted-living settings, the inclusion criteria must be broad. During the recruitment process, the most common reason for study withdrawal was "I'm too old for this". Similar findings were made by Tsai et al. ${ }^{34}$. When senior researcher JV visited the participating site, one group of older women had already decided not to participate in any research. We were not able to change their opinions on research during the two-week recruitment period. This kind of 'group effect' was not found in literature when the intervention was planned, and it highlights the importance of good communication between the research group and the participants ${ }^{18}$. Another possible reason behind withdrawals and the poor effect of the pedometer on motivation for some participants could be that throughout most of their lives, the participants had been told that physical inactivity was necessary for the appropriate treatment of illness ${ }^{35}$. The older adults are also at a disadvantage compared to other age groups because fewer of them grew up with a culture of physical activity ${ }^{35}$.

This study has several limitations. Firstly, the small sample was limited to just one residential facility. Secondly, the participants may have represented a select group of motivated individuals. For some reason, four of the five men living in the participating site agreed to participate in this study, and we received refusals mainly from women. It is not possible to determine whether it was the exercise in general or the pedometer program that was unappealing to those who did not agree to participate. Thirdly, the recruitment and study process was conducted by a research group unknown to the residents and the nursing staff. The motivational process could have been more effective if the dialogue between the staff and the research group would have been more fluent. The final and most important limitation was the pedometer itself. We found inaccurate pedometer recordings and attachment problems that most likely contributed to an underestimate of the number of steps taken and lack of statistically significant differences post intervention. Despite these limitations, the findings of this pilot study raise some technical development requirements for industry.

Simple technical solutions without numerous other complex functions besides the counting of steps are needed to meet older populations' needs. The possibility of visual impairments should be taken into account by building clearer and larger screens on the pedometers. Larger, easy to maneuver attachments should also be considered in the design, and better clips or magnet attachments should be provided to prevent dislodging. Most importantly, reliable and valid solutions for measuring steps taken with low walking speeds, shuffling gaits and walking aids are urgently needed as the older population increases. The possible role of the pedometer in encouraging residents of assisted-living facilities to walk, the characteristics of the older adults who might benefit most from the application of this technology as well as the 


\section{Pedometer-based walking}

use of pedometers in rehabilitation nursing are areas still in need of further research.

We chose to study a frail group of older adults living in assisted-living settings. This group is usually ruled out of research of pedometer-based activity programs directed to older adults, and this selection of a new interesting study group represents a great strength of the study. This pilot revealed important insights on the issues that need to be taken into account in future research. The issues were related to the technology used, the recruitment process, teamwork with the participating sites' staff and older adults' own expectations differing from those of the researchers.

\section{Acknowledgement}

We thank residents and staff of the assisted-living facility for their help and support.

\section{References}

1. U.S. Department of Health and Human Services. Physical activity guidelines advisory committee report, chapter 5: Active older adults, 2008; www. health.gov/paguidelines/guidelines/chapter5.aspx; retrieved February 20, 2015

2. Pitkälä EM, Juola A-M, Kautiainen $H$, Soini $H$, Finne-Soveri H, Bell S, Björkman M. Education to reduce potentially harmful medication use among residents of assisted living facilities: A randomized controlled trial. Journal of American Medical Directors Association 15(12):892-898; doi:10.1016/j. jamda.2014.04.002

3. Vuorio S, Vãyrynen R. Muistisairaat asukkaat sosiaali- ja terveyspalveluissa [Residents with $\operatorname{cog}$ nitive impairments in social and health services], 2009; http://urn.fi/URN:NBN:fi-fe201205085208; retrieved September 13, 2014

4. Chou $\mathrm{CH}$, Hwang CL, Wu YT. Effect of exercise on physical function, daily living activities, and quality of life in frail older adults: A meta-analysis. Archives of Physical Medicine \& Rehabilitation. 2012;93(2):237-244; doi:10.1016/j. apmr.2011.08.042

5. Heyn P, Abreu BC, Ottenbacher KJ. The effects of exercise training on elderly persons with cognitive impairment and dementia: A metaanalysis. Archives of Physical Medicine \& Rehabilitation 2004;85(10):1694-1704; doi:10.1016/j. apmr.2004.03.019

6. Hsu YC, Chen KM. Challenges of doing intervention research with the elderly Taiwanese population: Example of a tai chi/movement therapy. Geriatric Nursing 2005;26(6):358-365; doi:10.1016/j. gerinurse.2005.09.016

7. Brown Cl, Redden DT, Flood KL, Allman RM. The underrecognized epidemic of low mobility during hospitalization of older adults. Journal of the American Geriatrics Society 2009;57(9):16601665; doi: 10.1111/j.1532-5415.2009.02393.x

8. Tudor-Locke CE, Myers AM. Challenges and opportunities for measuring physical activity in sedentary adults. Sports Medicine 2001;31(2):91-100

\section{Conclusion}

To succeed in an assisted-living facility setting, a pedometer-based walking program requires a carefully planned implementation strategy, an accurate and easy to use activity measuring device, integration into daily routines, and the application of motivational methods. The accuracy and reliability of the pedometer need to be improved to make it more suitable for use by older persons with shuffling and low-impact gaits. Better clips to prevent dislodging as well as easier to read numbers are also required. Overall, the findings of this study suggest that there is a need for improved pedometer technology for use by older adults with disabilities and impairments in mobility.
9. Bravata DM, Smith-Spangler C, Sundaram V, Gienger A, Lin N, Lewis R, Stave C, Olkin I, Sirard J. Using pedometers to increase physical activity and improve health: A systematic review. The Journal of the American Medical Association 2007;298(19):2296-2304; doi:10.1001/ jama.298.19.2296

10. Mutrie N, Doolin O, Fitzsimons CF, Grant $M$, Granat M, Grealy M, Macdonald H, MacMillan F, McConnachie A, Rowe D, Shaw R, Skelton D. Increasing older adults' walking through primary care: Results of a pilot randomized controlled trial. Family Practice 2012;29(6):633-642; doi:10.1093/ fampra/cms038

11. Snyder A, Colvin B, Gammack JK. Pedometer use increases daily steps and functional status in older adults. Journal of the American Medical Directors Association 2011;12(8):590-594; doi:10.1016/j. jamda.2010.06.007

12. Tudor-Locke C, Hart TL, Washington TL. Expected values for pedometer-determined physical activity in older populations. International Journal of Behavioral Nutrition \& Physical Activity 2009;6(1):59; doi:10.1186/1479-5868-6-59

13. Elo S, Saarnio R, Routasalo P, Isola A. Gerontological rehabilitation nursing of older patients in acute health centre hospitals: Nursing views. International Journal of Older People Nursing 2012;7(1):46-56; doi:10.1111/j.17483743.2011.00277.x

14. Johnson J. Achieving effective rehabilitation outcomes: Does the nurse have a role? British Journal of Therapy and Rehabilitation 1995;2(3):113-118

15. Routasalo $P$, Wagner L, Virtanen H. Registered nurses' perceptions of geriatric rehabilitation nursing in three Scandinavian countries. Scandinavian Journal of Caring Sciences 2004;18(2):220-228; doi:10.1111/j.1471-6712.2004.00273.x

16. Gine-Garriga $M$, Roque-Figuls $M$, Coll-Planas L, Sitja-Rabert M, Salva A. Physical exercise interventions for improving performance-based measures of physical function in communitydwelling, frail older adults: A systematic review and meta-analysis. Archives of Physical Medicine \& Rehabilitation 2014;95(4):753-769; doi:10.1016/j. apmr.2013.11.007 


\section{Pedometer-based walking}

17. Harris $T$, Kerry S, Victor C, Ekelund U, Woodcock A, lliffe S, Whincup P, Beighton C, Ussher M, David L, Brewin D, Adams F, Rogers A, Cook D. Randomised controlled trial of a complex intervention by primary care nurses to increase walking in patients aged 60-74 years: Protocol of the PACE-lift (pedometer accelerometer consultation evaluation-lift) trial. BMC Public Health 2013;13:5; doi:10.1186/1471-2458-13-5

18. Knechel NA. The challenges of enrolling older adults into intervention studies. Yale Journal of Biology \& Medicine 2013;86(1):41-47

19. Cohen-Mansfield J, Werner P, Culpepper W], Wolfson M, Bickel E. Assessment of ambulatory behavior in nursing home residents who pace or wander: A comparison of four commercially available devices. Dementia \& Geriatric Cognitive Disorders 1997;8(6):359-365

20. Cyarto EV, Myers A, Tudor-Locke C. Pedometer accuracy in nursing home and community-dwelling older adults. Medicine \& Science in Sports \& Exercise. 2004;36(2):205-209; doi:10.1249/01. MSS.0000113476.62469.98

21. Folstein MF, Folstein SE, McHugh PR. "Minimental state". A practical method for grading the cognitive state of patients for the clinician. Journal of Psychiatric Research 1975;12(3):189198; doi:10.1016/0022-3956(75)90026-6

22. UKKInstitute. Exercizing pie for older adults after U.S. health resommendations. www.ukkinstituutti.fi/filebank/722-Yli_65_v_liiikuntapiirakka.pdf; retrieved September 29, 2014.

23. Holbrook EA, Barreira TV, Kang M. Validity and reliability of Omron pedometers for prescribed and self-paced walking. Medicine \& Science in Sports \& Exercise 2009;41(3):670-674; doi:10.1249/MSS.0b013e3181886095

24. Mahoney Fl, Barthel DW. Functional evaluation: The Barthel Index. Maryland State Medical Journal. 1965;14:61-65

25 Power $\mathrm{M}$. Development of a common instrument for quality of life. In: Nosikov A, Gudex C, editors. EUROHIS: Developing common instruments for health surveys. Amsterdam: IOS Press; 2003; pp 145-159

26. Arlt S, Hornung J, Eichenlaub M, Jahn $\mathrm{H}$, Bullinger $\mathrm{M}$, Petersen $\mathrm{C}$. The patient with dementia, the caregiver and the doctor: Cognition, depression and quality of life from three perspectives. International Journal of Geriatric Psychiatry 2008;23(6):604-610; doi:10.1002/gps.1946

27. Brooke J. SUS: A "quick and dirty" usability scale. In: Jordan PW, Thomas B, Weerdmeester
BA, McClelland AL, editors. Usability evaluation in industry. London: Taylor \& Francis; 1996; pp 189-194

28. Bangor A, Kortum B, Miller J. Determining what individual SUS scores mean: Adding an adjective rating scale. Journal of Usability Studies 2009;4(3):114-123; http://uxpajournal.org/wpcontent/uploads/pdf/JUS_Bangor_May2009.pdf; retrieved February 20, 2015

29. Fisher SR, Goodwin JS, Protas EJ, Kuo YF, Graham J, Ottenbacher K, Ostir G. Ambulatory activity of older adults hospitalized with acute medical illness. Journal of the American Geriatrics Society 2011;59(1):91-95; doi:10.1111/j.15325415.2010.03202.x

30. Institute of Medicine of the National Academies Report. Preventing medication errors. 2006; Washington: The National Academies Press

31. Leape L, Bates D, Cullen D, Cooper J, Demonaco HMS, Gallivan T, Hallisey R, Ives J, Laird N, Laffel G, Nemeskal R, Petersen L, Porter K, Servi D, Shea B, Small S, Sweitzer B,Thompson T, Vander Vliet M, Bates D, Hojnowski-Diaz P, Petrycki S, Cotugno M, Patterson $\mathrm{H}$, Hickey M, Kleefield S, Kinneally E, Dempsey Clapp M, Hackman JR, Edmondson A. Systems analysis of adverse drug events. Journal of the American Medical Association 1995;274(1):35-43; doi:10.1001/ jama.1995.03530010049034.

32. Oranta O, Routasalo P, Hupli M. Barriers to and facilitators of research utilization among Finnish registered nurses. Journal of Clinical Nursing 2002;11(2):205-213; doi:10.1046/j.13652702.2002.00587.x

33. Johnson JA, Mcllroy WE, Roy E, Papaioannou A, Thabane L, Giangregorio L. Feasibility study of walking for exercise in individuals living in assisted living settings. Journal of Geriatric Physical Therapy 2013;36(4):175-181; doi:10.1519/ JPT.0b013e318282d2d 3

34. Tsai PF, Chang JY, Chowdhury N, Beck C, Robertson PK, Rosengren K. Enrolling older adults with cognitive impairment in research: Lessons from a study of tai chi for osteoarthritis knee pain. Research in Gerontological Nursing 2009;2(4):228-234; doi:10.3928/1940492120090731-03

35. Phillips EM, Schneider JC, Mercer GR. Motivating elders to initiate and maintain exercise. Archives of Physical Medicine \& Rehabilitation 2004;85(7Suppl3):S52-57; doi:10.1016/j. apmr.2004.03.012 